\title{
Towards Re-conceptualising Leadership for Sustainable Peace
}

\author{
'Funmi Olonisakin*
}

\begin{abstract}
This article is motivated in part by the need to respond to the classical peacebuilding dilemma of 'conflict relapse'. It finds that international peacebuilding efforts rely overwhelmingly on person and position-based leadership perspectives, which provide mixed results at best. It argues that a process-based approach to leadership, rather than one that narrowly focuses only on particular personalities or individuals in formal positions of authority, offers a potential for peaceful solutions that are the product of interaction between those offering peace ideas and the whole of the affected society in response to their common situation. The paper thus proposes a framework for analysis and action in pursuit of sustainable peace. Questions that go to the heart of efforts to study and navigate a path to stable peace in a given situation should be systematically framed to take the following five things into account: the predominant situation; the degree of mutuality; the domains and societal levels in which emergent leadership is occurring to build a shared response to the situation; the quality of the leadership process - how influence is being exchanged between leaders and followers across domains and levels; and the degree of leadership effectiveness and movement toward peace or a return to conflict. This provides opportunities for peacemakers to pursue an inclusive, all-encompassing peace that can be sustained, not least because it concentrates attention on mutually held goals by people of the target society and their leaders.
\end{abstract}

\section{Introduction}

At first glance, the attempt to establish a connection between leadership and peace seems a colossal task. Such an impression is understandable for several reasons. First, each of these constructs has different definitions and wide ranging interpretations of the activities, which fall within these domains. As such, one recognizes these constructs when encountered but it is difficult to offer a general description that captures them in their entirety. Second, the two constructs are easily kept apart by an overwhelming focus on institutions, without careful consideration of the relationships that determine the effectiveness of those institutions. Points of interconnection between leadership and processes of building peace are however created by situations and phenomena such as armed and violent conflict. The post-Cold War experience of nearly three decades, in Africa, for example, suggests that the incidence of armed conflict in all its ramifications raises important questions about the role of leadership. To be 
certain, the connections between leadership and conflict resolution processes are well worth examining, not least in relation to the African continent that has experienced violent conflict in mutating ways since the end of the Cold War.

Scholars and observers of African affairs have discussed leadership in various dimensions in their analysis of Africa's political development since the 1960s. As discussed later in this paper, the academic focus on leadership has been less systematic across the last five decades despite the obvious preoccupation of popular literature with the failings of African leaders. There is broad consensus, for example, that the actions and choices of African leaders have some impact on the region's governance and development outcomes. ${ }^{1}$ Not unrelated, poor governance and development outcomes have numbered among the underlying causes of armed conflict on the continent. ${ }^{2}$ In the simplest sense, interrogating the cycles of conflict and the role of leadership in the causes and facilitation of conflict as well as in the efforts to manage conflict has some merit. However, it is the responses to the incidents of violent and escalating conflict in Africa in the nearly three decades since the end of the Cold War that draw particular attention to issues of leadership and offer vital lessons for the prevention of armed and deadly conflict. And it is these, which constitute the main focus of this article.

This article argues for a re-examination of peacebuidling through a leadership perspective that deviates from commonly held understandings of the concept. It begins by examining the conceptual underpinnings of peacebuilding and rifts in its practical application, particularly in Africa, which pose a dilemma for those seeking stable peace in situations of escalating or violent conflict. It then explores the ways in which leadership is generally conceived and how it is applied in efforts to build peace in practice, drawing out the underlying gaps in thinking and approach. The paper observes that by treating leadership unsystematically in peacebuilding processes and by regarding it as something that is based narrowly on perspectives of individual persons and positions that can be subsumed within the institutions created for peace, an opportunity for transformation is missed. Consequently, it argues that when leadership is conceptualised as process, it opens up the possibility of finding lasting solutions to conflict, from within the wider society. A process-based approach to leadership, rather than one that narrowly focuses only on particular personalities or individuals in formal positions of authority, offers a potential for peaceful solutions that are the product of interaction between those offering

\footnotetext{
${ }^{1}$ VonDoepp, Peter (2009), The Leadership Variable in Africa: Situating Structure and Agency in Governance Trajectories, Paper prepared for the 2009 Annual Meeting of the American Political Science Association, September 4, 2009, pp.3-4; also available at: https://ssrn.com/abstract $=1451730$

${ }^{2}$ See, for example, Zartman, I. William and Deng, Francis (eds) (1990), Conflict Resolution in Africa (Brookings Institution).
} 
peace ideas and the whole of the affected society in response to their common situation. The paper concludes by proposing a new framework for analysis and action in conflict-affected societies.

\section{The Peacebuilding Dilemma}

Perhaps the single, most important dilemma that has confronted those responding to conflict in Africa and elsewhere since the end of the Cold War is conflict relapse. This refers to recline into armed conflict in a number of situations that have experienced concerted peacemaking and peacebuilding interventions. Research has shown that a significant percentage of armed conflicts that conclude through negotiated settlement have a chance of relapse within ten years. Licklidier, for example, indicates that 50 percent of conflicts concluded through negotiated settlement between 1945 and 1993 suffered a relapse within a decade. ${ }^{3}$ Later analyses subsequently suggested that conflicts relapse within 10 years in 44 percent of cases $^{4}$ and 42 percent of cases respectively. ${ }^{5}$ Evidently, this dilemma is one that transcends African conflict situations as indicated by a number of peace processes globally that experienced initial failure such as Haiti, Timor Leste, and Kosovo among others. In Africa, this classical peacebuilding dilemma was exemplified by the Liberian civil war, the first such conflict to occur in Africa in the post-Cold War period, in which successive peace agreements collapsed. ${ }^{6}$ In the end, there were more than a dozen peace agreements in this conflict, which only began to produce a semblance of stability after 14 years. Other civil conflicts in Sierra Leone, Guinea Bissau and Somalia, for example, would later show similar patterns of relapse.

Dealing with this peacebuilding dilemma requires a commitment to preventing a relapse into violence and entails understanding and addressing the factors responsible for violent relapse. The need for prevention of armed conflict in the first instance and prevention of its relapse where conflict was not prevented seems obvious not least because of its devastating and deadly impact. In Africa,

\footnotetext{
${ }^{3}$ Licklidier, Roy (1995), 'The consequences of negotiated settlements in civil wars, 1945-1993', American Political Science Review 89(3), pp. 681-690 ; Kreutz, Joakim (2010), 'How and when armed conflicts end: Introducing the UCDP conflict termination dataset', Journal of Peace Research, 47(2), pp.243-250; and Picciotto, Robert, Olonisakin, Funmi and Clarke ,Michael (2007), Global Development and Human Security (New Brunswick: Transaction Publishers). ${ }^{4}$ Cousens, Elizabeth M. and Kumar Chetan (eds), Peacebuilding as Politics: Cultivating Peace in Fragile Societies (Bouler and London: Lynne Rienner, 2001)

${ }^{5}$ See, for example, Lacina, Bethany and Gleditsch, Nils P., (2005) Monitoring Trends in Global Combat: A New Dataset of Battle Deaths, European Journal of Population, 21, pp. 145-166.

${ }^{6}$ For a discussion of the Liberia peace process, see, for example, Lansana, Gberie (2005),

"Liberia's War and Peace Process", in FB Aboagye and AMS Bah, A Tortuous Road to Peace: The Dynamics of Regional, UN, and International Humanitarian Interventions in Liberia, ISS, Pretoria, pp. 51-70.
} 
the need to sustain peaceful solutions to armed conflict is also driven by other concerns, one of which is that African and international investments in responding to armed conflict in the region have yielded little or negligible dividends. This is evident, for example, in the continuation of recalcitrant conflict as seen in the Democratic Republic of the Congo where the UN has expended tens of billions of US dollars on peacekeeping operations in the last decade two decades. ${ }^{7}$ This is also seen in persistent and periodic low intensity conflicts like in Guinea Bissau, or indeed the outbreak of new forms of violent conflict as seen in Mali and most recently in South Sudan. Even in places where those investments appeared to have delivered visible peace dividend (Liberia, Cote d'Ivoire), we sometimes witnessed the retreat of conflict to locales within state boundaries where low intensity conflicts prevent the possibility of sustainable peace and development.

It was the search for an end to armed conflict and recurrence of the associated violence that led former United Nations Secretary-General, Boutros-Ghali to propose 'post-conflict peacebuilding', which he defined as 'action to identify and support structures, which will tend to strengthen and solidify peace in order to avoid a relapse into conflict'. ${ }^{8}$ He considered this alongside other conflict resolution instruments including 'preventive diplomacy', whose goal is to remove the sources of conflict to prevent the outbreak of violence; 'peacemaking', which is intended to resolve underlying issues in a conflict following the outbreak of violence; and 'peacekeeping', whose purpose is to safeguard peace when fighting seizes and assist with implementing peace agreements. ${ }^{9}$

The nature of the "peace" which is to be sought in order to resolve armed conflict and prevent its relapse is one, which has assumed varied interpretations and dimensions in the last two decades. Indeed, long before Boutros-Ghali's agenda for peace, Johan Galtung offered a conceptualization of what that peace ought to look like. ${ }^{10}$ Two key features of that peace have been at the centre of peace studies literature in the last four decades. One concerns the need to address structural violence, whereby even when violence is not physically apparent,

\footnotetext{
${ }^{7}$ The budget for MONUSCO for July 2013 to June 2014, for example, stands at USD 1.46 billion. The budgets for subsequent years have also been in excess of one billion US Dollars. The approved budget for July 2017 to June 2018 is USD 1,141,848,100. See, for example, http://www.un.org/en/peacekeeping/missions/monusco/facts.shtml ${ }^{8}$ Boutros-Ghali, Boutros (1992), An Agenda for Peace: Preventive Diplomacy, Peacemaking and Peacekeeping, Doc A/47/277 - S/24111, United Nations, 17 June 1992. Available at: http://www.un.org/Docs/SG/agpeace.html (Accessed 15 April 2015)

${ }^{9}$ Ibid

10 Galtung, Johan (1969), 'Violence, Peace and Peace Research', Journal of Peace Research, 6(3), pp. 167-191
} 
citizens are systematically denied access to sources that can guarantee their wellbeing and realization of their potential. These are the very factors that invariably produce violent conflict. A second and related feature, therefore, is the pursuit of positive peace rather than negative peace. While negative peace occurs with the mere absence of armed conflict, positive peace transcends this and entails building relationships that promote conciliation and cooperation within a society. In the absence of such foundations of peace, conflict has the potential to escalate into societal unrest and armed violence thus creating or deepening insecurity across the affected society.

In seeking an end to the insecurity created by the intra-state armed conflicts of the 1990s, the path to the kind of peace proposed by Galtung was often forged through a range of 'post-conflict' activities. In its usage here, the term postconflict refers to a period after the cessation of armed violence, when it is possible for conflicting parties to pursue their conflict through non-violent means. The experience of the last two decades suggests that such post-conflict peace building aspirations and activities can be clustered into five broad groupings. ${ }^{11}$ First, are those intended to protect the gains realized in the peacemaking process including where the aim is to maintain an arranged truce between warring factions. Peacekeepers and the security establishment play an important role in this regard. Ensuring that this truce is long lasting is often one of the main goals of those seeking to achieve stable peace in such situations. Typically, peace in this environment remains negative until that society is moved toward reconciliation and more stable peace.

Second are those activities, which focus on rebuilding infrastructure particularly those destroyed during the period of armed conflict. In post-conflict settings, this has entailed, for example, the reconstruction of schools, bridges, health facilities, among others destroyed during wartime. Third are those activities that seek to promote the building of institutions of governance. Typically, elections are a part of the process of securing this process of institution building. The fourth cluster of activities, are those that seek to promote reconciliation. It is possible to see this as occurring in stages right from initial attempts to negotiate an end to violence. The role of third party actors such as mediators is crucial in this regard. By the time a peace plan is accepted by conflicting parties, efforts move toward the need to remove structural violence. In more structured peacemaking arrangements, truth and reconciliation commissions are seen as a crucial part of

\footnotetext{
${ }^{11}$ Some of the activities described here have been more rigidly categorised by international actors, not least the United Nations (UN) as seen for example, in the outcomes of an international forum devoted to dealing with this issue through the reinvention of governance: UN Department of Economic and Social Affairs, The Challenges of Restoring Governance in Crisis and Post-Conflict Countries, UN- DESA and UNDP, $7^{\text {th }}$ Global Forum on Reinventing Governance Vienna, 26-29 June 2007. See pp. 14-17
} 
forging reconciliation. Fifth are activities that seek to "jumpstart" the economies of conflict-affected societies through for example, establishing an equitable formula for the management and distribution of available natural resources.

Not unusually, many, if not all of these activities have come under the label of peacebuilding, thus reflecting the wide-ranging meanings and interpretations given to the term. This is consistent with Boutros-Ghali's extensive description of peacemaking processes and peacekeeping operations, whose mandates were invariably expanded to deal with a range of multi-dimensional activities. As earlier outlined by Boutros-Ghali in his Agenda for Peace:

'Peacemaking and peacekeeping operations, to be truly successful, must come to include comprehensive efforts to identify and support structures, which will tend to consolidate peace and advance a sense of confidence and wellbeing among people. Through agreements ending civil strife, these may include disarming the previously warring parties and the restoration of order, the custody and possible destruction of weapons, repatriating refugees, advisory and training support for security personnel, monitoring elections, advancing efforts to protect human rights, reforming or strengthening governmental institutions and promoting formal and informal processes of political participation'. ${ }^{12}$

Boutros-Ghali was clear that peace building has two important underpinning and interlinking dimensions - one aimed at rebuilding institutions and infrastructures; and the other, which seeks to reconcile erstwhile adversaries, locked in bitter struggle, not least by addressing the root causes of conflict.

Yet questions persist as to why many conflict situations do not find lasting resolution, why elections do not lead to stable security and development outcomes, why the deep-rooted causes of the conflicts remain unaddressed, and in particular, why societies return to war and armed conflict. In recent times, some of these conflicts have mutated to include various dimensions of insecurity that pose equally significant threats to conflict affected societies. The conflict situation, which escalated from 2012 in Mali, and its intersections with violent extremism come readily to mind. The classical peacebuilding dilemma, however, poses a challenge for peacemakers across various contexts as has been experienced in recent years in places like Sudan, South Sudan, the DRC and Somalia to name a few. The inadequacy of an approach, which seeks to superimpose a rigid template that includes the activities outlined above as a formula for peace is reflected in the absence of the kind of stable peace about which Galtung wrote several decades ago. To be certain, these templates

12 Boutros-Ghali (1992) 
demonstrate recognition of the need for such stable peace but the effort to achieve this is confined by the neatly compartmentalized and institutionalized frameworks.

\section{The persistence of violent conflict and failure of peacebuilding}

In Africa, continued instability both in contexts that have experienced open armed conflict and in places, which have not experienced an outbreak of armed conflict points to the absence of stable and sustainable peace. The pointers to continuing instability and insecurity exist in the various low intensity conflicts or large scale insecurities that continue to impede normal development. Even in some societies that have not experienced large scale armed conflict stable peace has proven elusive. Guinea Bissau and Niger are just few examples in Africa. The search for explanations for this lack of progress has produced a number of studies that have sought to investigate the reasons for persistence of or recurrence of violent conflict after a peace agreement has been concluded. Several of those reasons are worth highlighting here to the extent that they help shed further light on the conceptual linkages intended. One factor that has been emphasized in several sources as an explanation for why peace fails is the failure to deal with the root causes of the conflicts. Werner, for example, argues that conflict recurs in part because conflicting parties fail to obtain a resolution to the underlying issues..$^{13}$ In many situations, violence recurs because the expectations that justice will be done, or that at least the grievances that gave rise to the need to resort to violence will be addressed are not met.

A second reason that has been alluded to within and outside UN sources is that the structured and by implication rigid nature of peace implementation, which typically locks parties into timelines tends to undermine the peace agreement and reduced the chances for lasting peace. This, for example, stifles the potential for transformation, which might normally occur organically through an unstructured process of societal interaction and relationship building. As early as 1995, there was a real recognition that implementing a peace agreement in conflict-affected societies within a set timeframe will not necessarily bring lasting peace. According to Boutros-Ghali:

'It is now recognized that implementation of the settlement in the time prescribed may not be enough to guarantee that the conflict will not revive. Coordinated programmes are required, over a number of years and in various fields, to ensure that the original causes of war are eradicated. This involves the building up of national institutions, the promotion of human

\footnotetext{
13 Werner, Suzanne (1999), 'The precarious nature of peace: Resolving the issues, enforcing settlement, and renegotiating the term', American Journal of Political Science, 43 (3), pp. 912-934.
} 
rights, the creation of civilian police forces and other actions in the political field.... only sustained efforts to resolve underlying socio-economic, cultural and humanitarian problems can place an achieved peace on a durable foundation'. ${ }^{14}$

In the pursuit of peace implementation, these underlying socio-economic, and cultural problems and the original causes of war to which Boutros-Ghali referred, typically receive far less attention. Indeed, it is arguable reversals are sometimes suffered in the peace process because greater emphasis is placed on the creation of structures far above the process of relationship building, which offers the potential to deal with the bitterness underlying conflicts between groups in societies that were locked in bitter struggle over a long period. Lederach refers to this as the 'justice gap' and the 'process-structure gap'. ${ }^{15} \mathrm{He}$ sees conflict transformation as the crucial window to stable peace. Using negotiation and mediation as entry points, he argues for transforming conflicts by tackling the relationships, and interests that sustain violent conflict. Removing structures that promote violence as well as the conflictual issues from a relationship invariably ensures that the locus of violence does not shift from one venue to another thus rendering the conflict intractable. ${ }^{16}$ These potentially entrenched cycles of violence have come to characterize much of the armed conflicts of the past two decades.

However, this approach to conflict resolution requires careful understanding of the issues underlying a conflict as well as time commitment to accompany the process. The frameworks and institutionalized approaches to making and building peace by the international community are not compatible with this idea since the requisite investment of time and resources that this process demands has not always been possible. This is in addition to structured, pre-arranged and superimposed models that leave little room for the emergence of transformative formulas from within affected societies as further discussed below. This is perhaps the main drawback and a problem inadvertently created by a seemingly

\footnotetext{
14 Boutros-Ghali, Boutros (1995), Supplement to An Agenda for Peace: Position Paper of the Secretary-General on the Occasion of the Fiftieth Anniversary of the United Nations, Report of the Secretary-General on the Work of the Organization, Doc. A/50/60 - S/1995/1, 3 January 1995. Available at: http://www.un.org/Docs/SG/agsupp.html (Accessed 15 April 2015) 15 Lederach, John Paul (1999), Just peace - The Challenge of the Twenty-First Century (Utrecht: European Center for Conflict Prevention); John Paul Lederach People Building Peace, available at www.gppac.net. See also, Picciotto Robert, Olonisakin 'Funmi and Clarke Michael (2007), Global Development.

${ }^{16}$ See Lederach, John Paul (1997) Building Peace: Sustainable Reconciliation in Divided Societies, (Washington, DC: United States Institute of Peace Press); Lederach, John Paul(1995), Preparing for Peace: Conflict Transformation Across Cultures. (NY: Syracuse University Press); and Lederach, John Paul (1999), The Journey Toward Reconciliation (Pennsylvania: Herald Press).
} 
sincere attempt by the UN system approach to the resolution of difficult armed conflicts.

All of this could be viewed in the context of the approaches to resolving conflict in the aftermath of Boutros-Ghali's unveiling of Agenda for Peace. In the more than two decades since then, we have seen dominant narratives and approaches emerge, which have been at the core of prominent critiques. The liberal peace agenda is one example. Agenda for Peace opened the way for the pursuit and application of 'liberal peace' particularly in war-affected countries that experienced UN intervention. The effort to help these countries return to a semblance of peace has meant a focus on governance re-building at multiple levels from local to international. ${ }^{17}$ In time, this has assumed a 'Liberal Peace' framework, with clear elements, many of which were outlined above. To be sure, these elements have typically included democratisation, human rights, rule of law and liberalized economy. ${ }^{18}$

Integral to the liberal approach is therefore the idea of statebuilding as peacebuilding, which is underpinned by the assumption that states affected by armed conflict are inherently weak. The centrality of statebuilding to peacebuilding is justified on the basis that the capability of such weak states must be developed to enable them effectively perform both coercive and noncoercive functions as advanced by Weber. ${ }^{19}$ The coercive functions entail the state's ability to successfully maintain legitimate control over the means of violence. This provides a sound basis to effectively extract revenue through taxation or natural resource exploitation. ${ }^{20}$ The non-coercive functions often have to do with a state's provision of social goods and services and efficacy of a state's governance structures -political, social and economic. ${ }^{21}$ As such, peacebuilding interventions have tended to deploy the liberal peace template in response to conflict affected states, not least in Africa.

\footnotetext{
17 Boutros-Ghali (1992)

18 See Richmond, Oliver (2008), Peace in International Relations, Routledge, p.3; see also

MacGinty, Roger and Richmond, Oliver, (2009), Liberal Peace and Post-War Reconstruction, Routledge, for a more expansive discussion.

${ }_{19}$ Weber Max, Gerth Heinrich H., and Mills C. Wright, (eds.), trans, 1946, From Max Weber: Essays in Socioplogy, (Oxford University Press: New York), pp. 77-128

20 See, for example, Tilley, Charles (1975), Western State-making, pp. 601-639; Tilly, Charles (2009), War Making and State Making as Organized Crime, pp. 169-191

21 See, for example, Pierson, Christopher (2004), The Modern State; Brautigam, Deborah, OddHelge, Fjeldstad, and Moore, Mick (2008), Taxation and State-Building in Developing Countries: Capacity and Consent (Cambridge University Press); Wai, Zubairu, (2012), 'Neo-patrimonialism and the Discourse of State Failure in Africa.' Review of African Political Economy 39(131), pp. 27 43.
} 
While the liberal peace agenda has been the subject of much critique over time,22 and has continued to evolve, this paper is less concerned with these critiques. Rather its concern relates to the mixed results of this approach to intervention and one evident outcome, which is the challenge of violent conflict relapse. This challenge continues to occupy the attention of the United Nations (UN) and was in part, the focus, for example, of the UN Advisory Group of Experts for the Review of the Peacebuilding Architecture in 2015.23

This paper is, thus an acknowledgement of the glaring absence of viable alternatives to liberal peacebuilding, which might practically address the persistence of armed conflict not least in places where much peacebuilding resources had earlier been expended. Arguably, in the absence of deep knowledge of the context or commitment of time and resources, it is tempting to retreat to the use of templates tried and tested elsewhere in pursuit of sustainable peace across post-conflict societies. All too often, such templates put structures first as if assuming that the relational aspects including reconciliation will catch up in time. The net effect of this is the cyclical pattern of conflict, intervention and zero sum politics that characterise peacemaking without genuine reconciliation in conflict affected societies. Perhaps even more importantly, these templates for peace often lack the capacity to prevent the outbreak of armed conflict in societies whose conflicts have not yet escalated to large-scale violence. This failure of technical approaches to peacemaking to find potentially transformative responses to recurrent conflict is what motivated the search for a more viable alternative. Interestingly, leadership receives peripheral treatment in discussions about causes of conflict and failures of peace efforts. As further discussed below, leadership is treated unsystematically and occurs largely in the discussion of the role of individual leaders (in Africa) in the escalation of conflict through poor governance; and in the lack of commitment shown by political leaders toward the peace and governance reforms. Arguably, leadership is a missing element in understanding or assessing the effectiveness or outcomes of peacebuilding. It is to the subject of leadership and its connections to peacebuilding that this article hereafter directs attention.

\footnotetext{
${ }^{22}$ For a more detailed discussion of contemporary discourses on peacebuilding see, for example, Call, Charles and Cook, Susan (2003), On Democratization and Peacebuilding, pp. 233-246; Call, Charles and Cousens, Elizabeth (2008), Ending Wars and Building Peace, pp. 1-21.

${ }^{23}$ United Nations (2015), The Challenge of Sustaining Peace: Report of the Advisory Group of Experts on the UN Peacebuilding Architecture. Available at:http://www.providingforpeacekeeping.org/project/the-challenge-of-sustaining-peace-reportof-the-advisory-group-of-experts-on-the-review-of-the-un-peacebuilding-architecture-2015/
} 


\section{The leadership factor in the search for sustainable peace}

At all stages of conflict and its management, and in the search for stable peace in Africa, leadership has been featured in dialogues both in popular (societal) spaces as well as in grey and academic literature. In popular terms, public opinion through media including art and music are not short of regular, if not daily reference to what is often termed "bad leadership" in explaining Africa's instability and resulting insecurity even if seen only through the prism of development gaps, political instability and inability of institutions of state to be responsive to the needs of citizens. Governance and development outcomes in Africa have on balance, been in deficit notwithstanding a small number of high performing countries. ${ }^{24}$ Observers and commentators alike have identified leadership as a determining factor in these outcomes. ${ }^{25}$ This easily connects with the storyline provided by analysts seeking to explain the underlying causes of conflict. However, there is often no systematic engagement with what leadership really means in these contexts. Typically, a great deal of focus is placed on individual leaders and their actions or inactions, which in many cases serve to undercut rather than bolster the potential for peace and prosperity that exists in society. Far less attention is focused on 'how' the exercise of leadership occurs in the particular contexts.

Similarly, in grey literature and policy dialogues in particular, leadership is a silent, ever-present factor. Typically, leadership is implicated in discussions about governance of conflict-affected societies. At the same time, there is no robust engagement with how leadership impacts upon these societies in the making of conflict, as well as in conflict management and peacebuilding. In a typical peace process, while leadership is taken into consideration, it is not a prominent item on the agenda beyond peacemakers' central engagement with protagonists who invariably become the centrepiece of political dialogue. Much attention is paid to the establishment of institutions, which according to North, is about establishing 'a stable environment of rules and procedures, ${ }^{26}$ and which could ensure predictability and sustainability of any (security and development) outcomes.

In this sense, although the institution building focus in the UN peacebuilding agenda does not preclude leadership dimensions, it is often not in policypractitioners' direct view. Implicitly, the focus on institution building is consistent with the underlying principle absorbed by institutions of global

\footnotetext{
${ }^{24}$ See Mo Ibrahim Index of Governance. Available at http://mo.ibrahim.foundation/iiag/downloads/

25 VonDoepp (1990), p.2.

26 North, Douglass (1990), Institutions, institutional change and economic performance

(Cambridge: Cambridge University Press)
} 
governance, for example, that effective institutions will regulate political and administrative behaviour. Presumably, such institutions will invariably incorporate the leadership question into their internal processes. To be certain, this focus on institutions is justified not least because when institutions ensure sustainability and stability when they function effectively. The challenge, however, which perhaps explains in part, the peacebuilding dilemma discussed earlier in this paper, is that the building of effective and durable institutions, must depend primarily not on outsiders but an organic "home-grown" process in the target society.

In conflict affected societies, where institutions might be relatively weak or perhaps non-existent, leadership becomes a very important variable in the process of building peace and stability. The weakness of Africa's institutions is an issue, which transcends the realm of politics, peace and security. For example, a great part of the debate among development analysts and practitioners has been the extent to which the African state is rooted in African society. ${ }^{27}$ That this is a debate to be had at all partly indicates the challenge of creating and sustaining homegrown institutions. Johnston, expands on this for example, by arguing that Africa 'requires the reconstruction of its public sector and its other institutions. In order for the state to be reconstituted and to recover its credibility, such a reconstruction programme will have to be anchored among the broad population'. ${ }^{28}$ However, despite the recognition of the weakness of Africa's institutions by policy practitioners, typically, leadership is analysed and engaged with in the most simplistic of ways during peace processes as discussed later.

The policy approach, which prioritizes institution building without a systematic connection to leadership and that is reinforced in grey literature, is not inconsistent with the academic study of leadership particularly as it relates to governance and politics in Africa. Indeed, and as further discussed below, political science aligns itself within the institution-building approach. The systematic study of leadership is given less focus by political scientists - at least not in the same way that psychologists, sociologists and management scholars have engaged with the subject - and it is worth investigating the reasons for this. One explanation is a methodological one. Leadership is deeply complex and does not easily lend itself to generalisability among case studies. The fact however is that sociologists and psychologists are at least able to navigate this challenge in their study of organisations. ${ }^{29}$ If anything, there is a case to be made for a

\footnotetext{
${ }^{27}$ Hyden, Goran (1992), 'Governance and the Study of Politics', in Hyden, Goran and Bratton, Michael (1992), Governance and Politics in Africa (Boulder, Colorado; Lynne Rienner Publishers)

${ }^{28}$ Johnston, Anton (1998), 'On Developing Institutions in Africa', in Lennart, Wohlgemuth, et al (1998), Leadership and Institution Building in Africa (Nordiska Africa Institute: Uppsala), p.49. ${ }^{29}$ See Pierce, Jon L. and Newstrom, John (2008), Leaders and the Leadership process: Readings, self-assessments and applications (Boston: Mcgraw Hill)
} 
multidisciplinary approach when the leadership construct is being examined in relation to complex, loosely structured settings such as those that underpin peace and security challenges in African societies.

Perhaps a stronger explanation that can be made for political scientists' reticence in systematically studying leadership is the heavy influence of Western literature and indeed Global North experiences and societies where institutions are already well established and are in synch with the systems of governance. As such, political and administrative behaviour is easily shaped and regulated by a culture of rules, procedures tried and tested over centuries. African states, by comparison, are more recent and have undergone a different trajectory in which arguably, given externally imposed systems and institutions, their states are not the direct products of their old societies and traditions. Leadership therefore becomes crucial to building, strengthening and sustaining such institutions of governance and thus critical to building the foundations of peace and stability. All of this notwithstanding, when taken as a whole and viewed over a longer period, leadership has been a recurring theme in the study of political governance in Africa. In the immediate post-independence period, African leaders - military and civilian alike - featured in the analysis of early modernization theorists. ${ }^{30}$ Overwhelmingly, modernization theorists placed much emphasis on the leaders of the new states and predicted success without adequate focus on the surrounding conditions. After just over a decade, revisions began to occur in this perspective as the leaders and the states failed to deliver on the anticipated progress. The upshot of the failed expectations was an increasing focus on contextual issues, including socio-economic influences and nature of political institutions. ${ }^{31}$

A new focus on leadership in the mid-1980s emphasized the crucially important role that leaders could play in the promotion of "good" governance. Leadership was found to be a key variable in the effort to achieve "political institutionalization" in Africa notwithstanding the evident structural challenges. The impact of leadership styles on their effectiveness in governance was given particular focus by Cartwright, for example. ${ }^{32}$ In the atmosphere of conflict and instability that engulfed much of Africa at the end of the Cold War, the contextual

\footnotetext{
${ }^{30}$ See, for example, Pye, Lucien (1993), Politics, Personality and Nation-Building (New Haven, CT: Yale University Press); Janowitz Morris (1964), The Military in the Political Development of New Nations: An Essay in Comparative Analysis (Chingo: University of Chicago Press).

${ }^{31}$ See, for example, Lemarchand, Rene (1972), 'Political Clientelism and Ethnicity in Tropical Africa: Competing Solidarities in Nation Building', American Political Science Review, 66(1), pp. 68-90; and Ake, Claude (1981), A Political Economy of Africa (New York: Longman).

32 VonDoepp, Peter (1990), p. 2; Jackson, Robert and Rosberg, Carl (1985), 'The Marginality of African States', in Carter, Gwedlyn and O'Meara, Patrick (eds), African Independence: The First Twenty-Five Years (USA:Indiana University Press); see also Cartwright , John (1983), Political Leadership in Africa (New York: St. Martin's Press).
} 
analysis and demands from reforms have also highlighted the vital role of leadership, emphasizing the need for leaders who would be more committed to reform. ${ }^{33}$ Emphasis on effective leadership as a condition for effective state institutions, which respond effectively to citizens and can deliver growth began to reflect a better grasp of the context. ${ }^{34}$ Even global institutions with a rigid focus on institutional frameworks started to shift, giving attention to the leadership factor.

The United Nations, the World Bank and others have come to identify "strong" leadership as a factor that is key to African countries' achievement of the development goals. ${ }^{35}$ Perhaps the most visible indicator of the focus that is given to leadership as an important variable in governance and development is the Mo Ibrahim Index of African Governance, which measures the impact of leaders' choices and decisions on the governance and socio-economic development outcomes across Africa. ${ }^{36}$ In this regard, the Mo Ibrahim Foundation's Award for achievement in leadership in Africa stands out. Apart from the honorary award to Nelson Mandela in the first year of this initiative in 2007, only four African leaders have met the criteria for the award. To many every day watchers of African governance, this reinforces the regular claims about "poor" leadership in Africa. ${ }^{37}$ Engagement with the subject of leadership in this regard reflects a notion and practice of leadership that is focused on individual leaders, often in formal positions of authority.

\footnotetext{
${ }^{33}$ See Hyden, Goran and Bratton, Michael (eds) (1992), Governance and Politics in Africa (Boulder CO: Lynne Reinner Publishers)

${ }^{34}$ Gyimah-Boadi, Emmanuel and Van de Walle, Nicolas (1996), 'The Politics of Economic Renewal in Africa', in Benno Ndulu et al, Agenda for Africa's Economic Renewal (Newbrunswick: Transaction Publishers).

35 See United Nations (2007), Economic Report on Africa: Accelerating Africa's Development Through Diversification (Addis Ababa, Economic Commission for Africa); World Bank (2009), Economic Development and the Quality of Legal Institution, Available at http://siteresources.worldbank.org/INTLAWJUSTINST/Resources/LegalInstitutionsTopicBrief.p df (Accessed 3 June 2017) ; and World Bank (2007), Leadership for Development Results: Country Case Studies (Washington DC: The World Bank Institute)

${ }^{36}$ See Mo Ibrahim Index of Governance, available at:

http://mo.ibrahim.foundation/iiag/downloads/

${ }^{37}$ See, for example, Chutel, Lynsey (2017), 'The African award that seems to pride itself on not finding a winner strikes out again', Quartz Media LLC, 28 February, available at: https://qz.com/920981/the-2016-mo-ibrahim-prize-for-african-leadership-choose-not-name-awinner/(Accessed 3 June 2017)_; and Taylor, Adam (2015), 'The sad story of Africa's most prestigious prize', Washington Post, 4 March, available at: https://www.washingtonpost.com/news/worldviews/wp/2015/03/04/the-sad-story-ofafricas-most-prestigious-prize/?utm term=.e141d0306a9c (Accessed 3 June 2017)
} 
The question then arises as to the usefulness of this approach to leadership for the kind of peacebuilding thinking and analysis at the core of this paper. The connection of all of the leadership discussions above with conflict and peacebuilding appears fairly logical when considered from the perspective that poor governance and development outcomes can lead to instability and conflict. And if poor and ineffective leadership was a key variable in producing those outcomes, then logically, leadership is a factor at the root of armed conflict. The argument that more responsible and effective leaders will reverse this, while eminently sensible, offers no stable way to understand how that effectiveness might come about. Arguably then, the dominant view of leadership portrayed in the political science literature so far has limited usefulness for peacebuilding analysis, policy and practice. As such, with few exceptions, this approach to leadership, which focuses on the actions of individual leaders typically located in the top echelon of the political class, does not provide a useful analytical framework for building the type of stable peace described earlier in this paper. And it does not so much lend itself to policy and practical application.

One of the relatively few attempts by political scientists to systematically engage the study of leadership and its impact on politics and development is Vondoepp's proposed framework for comparing leader behaviour such that there is improved understanding of why certain leaders engage in 'governance and development enabling behaviours' in some situations but do not in other situations. ${ }^{38}$ This line of inquiry begins to help develop a systematic approach to the study of leadership in relation to political and economic governance, which in turn provides some basis to interrogate contexts in which governance deficits have led to conflict. It also begins to engage the methodological issues, which underline the reluctance to critically engage the study of a deeply complex construct such as leadership. This complexity is further discussed below. Still, Vondoepp's framework, to a large extent focuses on leaders in particular positions of authority although his attempt to connect their agency with the underlying structure is commendable.

How then must leadership be understood and framed if it is to have a transformative value for the peacebuilding dilemma and path breaking influence on peacemaking in recalcitrant conflicts some of which have occurred in Africa? There is need for a real shift in the use and interpretation of leadership conceptually and practically - by various publics and actors such that their interpretations invariably impact on the articulation of policy and the practical application of such policy. To be sure, the varied interpretations and meanings ascribed to leadership reflect the complexity of the construct. Taken from the perspective of different interlocutors, the interpretations of leadership that they

${ }^{38}$ Vondoepp (1990), 'The Leadership Variable in Africa...', pp.4-8. 
offer seem logical. This complexity is captured in the leadership literature. African and indeed global publics see leadership as something relating to the individual (usually political) leader. These are the most visible symbols of leadership in society. Alongside this is the tendency to see leadership in hierarchical terms. In addition, policy actors see leadership as part of the function of particular institutional and organizational frameworks. But none of these perspectives has consistently explained or delivered sustainable peace, in conflicts in Africa or other regions.

Luc Reychler and Anton Stellaman's study is among few attempts to explore the leadership dimensions of peacebuilding. It identifies a 'critical mass of peacebuidling leadership' as one of the essential preconditions of sustainable peace. ${ }^{39}$ The authors argue that this, alongside four other building blocksare mutually reinforcing and must be present at the same time for sustainable peace to be realized. The other building blocks include 'an effective system of communication, consultation and negotiation, peace-enhancing structures and institutions, an integrative political-psychological climate... and a supportive international environment'. ${ }^{40}$ The dearth of one of these building blocks can potentially render an entire peacebuilding process ineffective. ${ }^{41}$

This all-encompassing conceptualisation offers an expansive yet integrated approach to peacebuilding. Like dominant approaches, it includes installation of democratic political, economic and security structures and institutions. But it also gives equal attention to the less tangible dimensions of peacebuilding - the creation of an 'integrative climate', which can produce cooperative attitudes behaviours and institutions. Furthermore, it gives prominence to the interaction of a critical mass of peacebuilding leadership, acknowledging other works that stress the presence of such leadership across domains and at multiple levels elite, middle and grass root. ${ }^{42}$ Additionally, the focus on leadership acknowledges the presence of leaders outside of the formal realm. ${ }^{43}$ In addition to people with formal authority, 'leadership is also exercised by people without formal authority... [who] provide the capacity within the system to see through the

\footnotetext{
${ }^{39}$ See Reychler, Luc and Stellamans, Anton (2004), 'Researching Peace Building Leadership,' Paper presented at the Conflict Resolution and Peace Building Commission (CRPB) at the International Peace Research Association in Sopron, Hungary, July 2004; See also Reychler, Luc (1999), Democratic Peace-Building and Conflict Prevention: The Devil is in the Transition, Leuven University Press, Leuven for a discussion of some of the key features of sustainable peace agenda ${ }^{40}$ Reychler, Luc and Stellamans, Anton (2004), p.3

${ }^{41}$ Ibid

42 Lederach, John Paul (1997)

${ }^{43}$ Heifetz, Roland (1994), Leadership without easy answers, The Belknap Press of Harvard University Press, Cambridge Massachusetts; see also Heifetz, Roland A. and Linsky, Marty (2002), Leadership on the Line: Staying Alive through the Dangers of Leading (Harvard Business School Press)
} 
blind spots of the dominant viewpoint'. ${ }^{44}$ The outcome of a peace process will depend to a great extent, on the way in which these building blocks are established and managed. Timing, prioritization and mutual interaction of these building blocks require more than just a technical input or technocratic decisionmaking process. ${ }^{45}$

Perhaps an even more original contribution of this study, which moves it beyond a template-driven approach and brings in a leadership dimension, is its analysis of peacebuilding as an adaptive challenge. When considered along a continuum in which challenges occur, peacebuilding is located at an extreme end in which problems may not be clearly defined and technical or quick fixes are not available. With this adaptive challenge, problem definition as well as solution finding would require learning. This is in sharp contrast to the other end of the spectrum, where problems are of a technical nature and thus require technical solutions -which can be expert led and managed. 46 This consideration of peacebuilding as an adaptive as opposed to a technical challenge offers the potential to undertake careful learning, which pays greater attention to solutions available in the very societies to which peacebuilding is targeted. This might help peacebuilders avoid the temptation to retreat to templates and offer the possibility of stable and sustainable peace.

One drawback in these authors' path-breaking conceptual work is that having argued for a critical mass of peacebuilding leadership as opposed to 'peace inhibiting leadership', it then relies on an unambitious design in the gathering of empirical evidence to support this. To be certain, the study mentions explicitly, the need for a critical mass of peacebuilding leadership across multiple domains and at several levels from local to international as well as external and internal. It also sees leadership as central to the establishment of each of the building blocks discussed above. And it describes what this critical mass of peacebuilding leadership might look like when it is achieved: 'We can speak of a critical mass of peace building leadership when the influence of peace building leadership is greater than the influence of the spoilers of the peace building process.' ${ }^{47}$ Thus the next challenge to which the attention of that study was focused, was to distinguish peacebuilding leadership from non-peacebuilding leadership.

However, any assumption or expectation that this emphasis on "influence," its nature and process would be robustly engaged across domains and levels in a particular context, was not met in the subsequent research design and evidence gathering phase. Instead, the identification of manifest and potential

\footnotetext{
${ }^{44}$ Reychler and Stellamans (2004), p.7

${ }^{45}$ Ibid, p.5

${ }^{46}$ Ibid, pp. 7-8

${ }^{47}$ Ibid, p. 9
} 
peacebuilding leadership focused narrowly on studying 'people that were recognized as either peacebuilders or war mongers.' ${ }^{48}$ This exclusive focus on individual leaders rather than an initial focus on manifestations of influence toward peace or discord in the target society on each of the building blocks earlier specified diminished the quality of the findings. The framework of analysis that was developed (focusing on particular leaders' values, analytic style, change behavior, and motivation and personality ${ }^{49}$ was too leader centric to draw meaningful conclusions about how leadership can transform peacebuilding toward sustainable peace. What was potentially path-breaking work had fallen into the same trap of exploring leadership only through the lens of individual leaders. Yet, the achievements or failures of those leaders do not offer a consistent narrative about the essential building blocks of peacebuilding that the study outlined at the start. Arguably, research that can usefully transform peacebuilding must seek to re-conceptualise leadership away from the narrow focus on leaders and provide a framework of analysis that provides a stable approach to studying leadership and peace. It is to this issue that this paper must now turn.

\section{What leadership perspective is most viable for pursuing sustainable peace?}

Academic literature engages leadership more scientifically thus exploring the phenomenon from its various perspectives and across disciplines. In so doing, leadership exposes its complexity and presents various approaches to dealing with the construct. The study of leadership reveals a range of perspectives, which further confirms the complexity of this construct. Keith Grint, for example, offers four alternative definitions of leadership, which capture the complexity of leadership while focusing the analyst's mind on key issues surrounding its application:

- Leadership as position - where leaders operate ${ }^{50}$

- Leadership as person - who leaders are ${ }^{51}$

- Leadership as result - what leaders achieve 52

- Leadership as process - how leaders get things done ${ }^{53}$

The critiques of some of these approaches to leadership; and the questions thrown up by the conflict situations to which sustainable peace is being sought

\footnotetext{
${ }^{48}$ Reychler and Stellamans (2004), p.10

${ }^{49}$ Ibid

${ }^{50}$ Grint, Keith (2010), Leadership: A Very Short Introduction (Oxford: Oxford University Press),

p.4

${ }^{51}$ Ibid

52 Ibid

${ }^{53}$ Ibid
} 
invariably de-emphasize some definitions of leadership and draw attention to one in particular for the purposes of this paper. For example, defining leadership as position or as person- as typically done in the analysis of African politics and governance as well as the peacebuilding domain discussed above - does not adequately explain the absence of sustainable peace in a range of conflictaffected societies. This is particularly relevant for countries that benefit from massive injection of local and international investment in peacebuilding and yet find peace and stability elusive. It will be difficult, for example, to maintain a claim with consistency, that simply by occupying the position of Force Commander at the helm of a peacekeeping operation, or that of Special Representative of the UN Secretary-General leading UN's presence in a target country, one can bring about the realization of stable peace in a conflict situation. Furthermore, no matter how professional or charismatic occupants of these positions are, they will not deliver stable peace in every conflict situation. Even if the successful resolution of the odd conflict were to be attributed to the effective use of the authority of office and or the personal qualities of these leaders, this claim will not carry through in all conflict situations. As such, we will not come to a consistent and unchanging understanding of how stable and sustainable peace can be achieved by examining situations of conflict and peace building only through the actions of key personalities or of occupiers of positions of authority.

A results-based perspective to leadership has some relevance albeit it with considerable limitations. To be sure, a focus on results makes it possible to assess peacebuilding success through what peace leaders achieve in a peace process. It is not unusual for observers and participants in peace processes to count short-term outcomes and the reaching of particular milestones as indicators of success. This typically applies, for example, to ceasefire agreements, rebuilding of infrastructure, re-organisation and training of security sector personnel and the successful organizing of elections and/or plebiscites. It is difficult to challenge any claim that these results are markers of progress in a peacebuilding effort. And indeed they can be useful facilitators of important statebuilding conversations. But delivering these results yields relatively little for stable and sustainable peace if the process through which those results were achieved cannot withstand significant tests. Such tests relate, for example, to the scale of societal participation or degree of collective ownership of these activities; and fundamental to this, the intentions as well as the power dynamics that underpin them. All too often, these important elements of the architecture of peace have resulted from exclusionary processes driven by coercive power. The real challenge with a results-based leadership perspective is that it excludes the relational elements, which allow for a consideration of the mutual concerns and interests of leaders and followers, in essence, the protagonists and the rest of society. Thus, this approach will not necessarily produce the makings of sustainable peace. It is possible, for example, for a result to be achieved through 
coercion or through unscrupulous or exclusionary means but it might ultimately derail a peace process.

\section{Leadership as process}

A processed-based approach to leadership offers perhaps the most robust and all-encompassing framework of analysis for the pursuit of sustainable peace. Three integral elements of process-based leadership ensure a consistent engagement with the unending questions about the persistence of armed conflict and the failure to transform the issues involved in conflict in order to find and sustain peace. The first element is context. The nature of the situation that confronts a group or society invariably frames the leadership experience in that context. In conflict-affected settings, assessing the degree to which a situation is experienced across a target society constitutes an important entry point for leadership analysis. The second element thus has to do with mutuality - a sense of shared feelings or intentions among people experiencing a particular situation. Understanding the range of people or actors whose concerns and/or interests are mutually linked in a situation is crucial in a peacemaking effort. This makes it possible to assess, for example, the degree of fragmentation in society or indeed, the inclination to pull together thus offering the potential for collective solution finding across a conflict-affected society.

The third element is influence - how it is asserted, accepted and exchanged in a given situation. To be clear, influence is the heartbeat - the single most important driving force - of leadership. And it is the one element of the leadership process, which connects the other leadership perspectives discussed earlier. The nature of the interaction between leaders and followers is at the core of influence. In any situation, those with ideas to deal with the issues at hand, tend to assert influence on those mutually affected or concerned by that situation. When that influence is accepted, a leader (or leaders) would emerge in that situation. Those who become leaders in that setting are not necessarily those in assigned positions of formal authority. And those often referred to as followers, are in actual fact those who pursue shared goals with the leader(s). Since leadership in this regard is essentially a two-way influence relationship, those who receive the influence assertions often respond by asserting influence in return, that is, by making demands on the leader(s). "The very sustenance of this relationship depends upon some yielding to influence on both sides. ${ }^{54}$ Influence over others is thus 'purchased at the price of allowing one self to be influenced by others. 55 This 'exchange of influence' between leaders and

\footnotetext{
${ }^{54}$ Homans, George Caspar (1961), Social behavior: Its elementary forms (New York: Harcourt, Brace and World)

55 Ibid
} 
followers occurs when leaders respond to followers' demands as they collectively seek a solution to their common situation. This provides a basis for understanding how a new leader becomes legitimized in the perceptions of their peers.

Indeed, the nature of the interaction between leaders and followers and how leaders lead, is an important distinction between process-based leadership and other leadership perspectives. The leader's style as well as the base of their power would typically come into play here and can sometimes be a key determinant of effectiveness in leadership. The presence of an exchange of influence between leaders and followers in process-based leadership expands the base of the leader's power in influencing others toward a shared goal. It also tends to compel an ethical approach as it connotes a sense of "common good". The sources of power open to the leader could include those derived from both personal and position power, which French and Raven categorise as referent, expert, legitimate, reward and coercive power. ${ }^{56}$ With other leadership perspectives where the relationship between leaders and followers is not based on the pursuit of shared goals, the temptation to retreat to the use of coercive power and the pursuit of exclusionary agendas becomes greater. Notwithstanding the existence of favourable conditions for the pursuit of a shared goal between leaders and followers or other members of a group, the leader's style and approach is also a factor in determining effectiveness. There is no shortage of literature about leadership style. Much has been made for example, of the differences between transformational and transactional approaches to leadership, among others. ${ }^{57}$

Arguably therefore, peacebuilding contexts are better understood and the pursuit of sustainable peace is enhanced when leadership is approached from a process-based perspective. Those whose assertions of influence are accepted, who invariably become leaders in peacebuilding contexts may not hold formal positions in government or society and therefore do not rely on position power. They emerge probably because they offered the most viable ideas and solutions to the mutually felt needs of the affected society in that situation. External actors seeking to intervene in war-affected societies would do well to understand the context and recognize those leaders with whom a sufficiently broad crosssection of that society have mutually-held needs and goals. This offers a more viable path to peace rather than an approach that simply seeks to identify individuals outside of that context (or sometimes within) who may have

\footnotetext{
${ }^{56}$ See for example, Hinkin, Timothy R. and Schriesheim, Chester A. (1989), Development and application of new scales to measure the French and Raven (1959) bases of social power. Journal of Applied Psychology, 74(4), pp. 561-567

${ }^{57}$ See for example, Northouse, Peter G. (2016), Leadership: Theory and Practice, Sage, pp. 161193; Burns, James M. (1978), Leadership (Harper Perennial Political Classics), pp. 257 - 307.
} 
attractive personal qualities but are irrelevant to the situation at hand. As Albert Murphy states:

'Leadership comes into being when an individual meets certain social needs; when he/she releases in the social situation of which he/she is a part, certain ideas and tendencies, which are accepted by the group because they indicate solutions of needs which are dimly sensed'. ${ }^{58}$

Thus, in peacebuilding, as in other contexts, leadership does not reside in a person. As Murphy aptly reflects, leadership is a function of an entire situation; and leaders invariably 'rise and fall' as situations change not least because each situation demands certain types of actions and an individual may not consistently provide relevance across all situations. Defining leadership as process allows one to capture the dynamism of this construct in situations of conflict, which are especially defined by rapid change. Peacebuilding by its very nature - multi-dimensional and multifarious - exhibits similar dynamism. In this regard, this paper thus aligns itself with those who define leadership as a process of interaction between leaders and followers in responding to their mutual situations. ${ }^{59}$

Arguably, leadership emergence and succession in this process-driven way, often defines success in efforts to build lasting peace in conflict-affected societies. Leadership will emerge in response to situations of conflict, if allowed to develop organically or if observed differently as a process of influence, in which an individual 'releases into the social situation of which he/she is a part, certain ideas and tendencies, which are accepted by the group', emerge from any part or level of society and not just from an institutionalized, formal, hierarchical form. Any person or persons could emerge from any level of that society in response to their common situation. But typically, leadership in peacebuilding processes in much of Africa, for example, has often been conceived as part of an institutional framework in which leadership as person, position or results-based is privileged over leadership as a process of influence.

To be certain, process-based leadership does not delegitimize person-based or position-based leadership. The position of this paper is that popular as those approaches to leadership might be, they cannot be deemed an effective entry point for framing peace and security in conflict-affected societies. Taking process-based leadership as the main window to solution finding helps broaden the base of engagement and it does not preclude person or position-based

\footnotetext{
58 Murphy, Albert J. (1941), A Study of the Leadership Process, American Sociological Review, 6, pp. 674-687, Reprinted in Jon L. Pierce and John W. Newstrom (2008), pp. 12-14.

${ }^{59}$ For example, Northouse. (2016), p. 6; and Pierce and Newstrom (2008), pp. 3-6.
} 
leadership. Making leadership the entry point rather than individual leaders in high-ranking positions who are typically seen as a panacea, offers the possibility to engage all leadership perspectives. Whether the leaders who emerge are based at the pinnacle of society or its nadir, what matters for peacebuilding is that they emerged from a process that led to a collectively owned solution that offers a greater promise of stable peace. The argument here is that a systematic engagement with every conflict situation in a way that facilitates an organic process of interaction within affected society such that they can collectively engage the ideas for peace and conflict resolution, offers a better prospect of dealing effectively with the classical peacebuilding dilemma and reduces the incidence of periodic relapse into violence.

The origin of those seeking to build peace in a conflict situation is a factor that cannot easily be ignored in the analysis of the leadership dimensions of peacebuilding. The mutuality of the situation in which this influence is being exchanged by leaders and followers is not typically a major pre-occupation of those responding to conflict particularly if they are not part of the situation. Several factors account for this. Finding a quick end to violence often constitutes the immediate focus. The costs of facilitating a society-wide process in which leadership emerges organically in response to the situation on the ground are high and they offer limited expediency in comparison with rapid intervention. In addition, the natural tendency for actors external to a situation or outside the locus of conflict, when responding to situations of violent conflict is to superimpose their own models.

The models of peacemaking and peacebuilding prescribed by the United Nations, regional organizations and state actors often lean toward the creation of institutions or prescribed models. Transferring successes from elsewhere is easy for such outsiders. As such, these institutional and official approaches rely on assigned leadership, which invariably emphasizes person, position and results, with process given less priority. If and when leadership is exercised in those situations on the basis of exchange of influence, it is often the product of serendipity and not part of a planned approach or systematic response. The limitations of externally handed down solutions or institution-building projects which are not based on a locally driven process (whether in the realm of development or security) is aptly presented by Johnston and others in the following text:

'The process of indigenous institution building... is the way that societies seek to stabilize themselves... It is possible for external agencies to provide support to the reconstruction of Africa's institutions - not, however, from a dirigiste position, where the external agency decides what is best, and tries to force it through, but instead from a supportive position of understanding 
and respect for the recipient institution's culture and efforts. Certainly, organizations that do not correspond to society's concerns can be built but their possibility of 'institutionalizing' themselves will be extremely small'. ${ }^{60}$

\section{Toward a framework for analysing movement toward sustainable peace}

The dynamics of leadership and peace are best studied by examining situations of conflict and peacemaking on a case-by-case basis. It is difficult to generalize about the relationship between these two constructs across all situations. This does not preclude the possibility that very similar situations might reveal similar dynamics. But the fluidity of conflict spaces and the unpredictable of leadership contexts along with its complexity make any attempt to generalize a risky endeavour. To be sure, the context that surrounds peacebuilding efforts and processes vary and leadership dynamics in these settings are also bound to vary. The nature of the conflict and its impact on society as well as the process of intervening to build peace invariably determine the leadership dynamics and the potential for stable and sustainable peace. There are often stark differences between a situation in which a conflict has experienced the peacebuilding intervention of actors external to the conflict and one where a peacebuilding effort has evolved internally without significant external intervention. A number of questions become relevant in this regard. Is there a difference in the leadership dynamics in these situations? Which situations offer a higher chance of sustainable peace with a reduced chance of conflict relapse?

This paper has argued that process-based leadership offers the most appropriate framework for understanding and evolving a process that leads to sustainable peace in conflict-affected societies. A conceptual understanding of leadership as process compels a particular approach to framing questions that help investigate and navigate the path to building stable peace in target societies. The questions that researchers and peacemakers ask in order to understand and/or to act in those contexts must be sufficiently robust and offer the possibility of including and engaging evident patterns of influence in a given situation. Essentially, this inquiry must avoid retreating to simple and obvious pathways provided by dominant approaches, which might be laden with ideology and reliant on key personalities. As such, the entry point for a process-based leadership analysis will not be a leader. It must of necessity begin with a focus on the nature of the situation under investigation and the challenge it presents.

Questions that go to the heart of efforts to study and navigate a path to stable peace in a given situation should be systematically framed to take the following five things into account: the predominant situation; the degree of mutuality; the

60 Johnston (1998), p.49 
domains and societal levels in which emergent leadership is occurring to build a shared response to the situation; the quality of the leadership process - how influence is being exchanged between leaders and followers across domains and levels; and the degree of leadership effectiveness and movement toward peace or a return to conflict. Below are illustrative examples of questions that might help frame a process-based leadership approach to interrogating conflict-affected situations.

- The situation: What conflict or security situation confronts the society in question? What constitutes the most significant challenge to finding stable peace in that setting?

- Mutuality: Whose specific (security and development) concerns and interests are mutually connected in this situation?

- Leader emergence: Whose ideas and assertions of influence are widely accepted as a solution to the common situation faced by the society?

$\circ$ In what domains and at what levels of society are these ideas and assertions being made?

- How extensive is this influence in each domain and at each level?

- At what levels of society is this emergent leadership most evident?

- The leadership process: What is the nature of the interaction between emergent leaders and members of society or their distinct follower community in pursuit of their common goals?

$\circ$ How is influence exchanged between emergent leaders and wider society or follower community in relation to the common goals sought?

- How do the leaders lead and how do they respond to their followers' demands?

- What are the bases of power most accessible to the leaders?

- Is a distinctive pattern observable in any domain or level

- What approach to leadership or what style of leadership offers a potential to transform the conflict in the direction of stable peace or away from peace prospects?

- What particular qualities have proven most transformational in the leadership approach?

- Effectiveness of leadership for peace or conflict:

- What factors determined leadership effectiveness or ineffectiveness in this context?

- What issues, factors or actors proved decisive in the movement toward peace or conflict?

- To what extent did followers or societal perception of leaders in some domains or at some levels shape leadership effectiveness?

- What was the transformative moment in this process? 
Ultimately, a process-based leadership framework of analysis will expand thinking and understanding about the processes of bringing lasting peace to waraffected societies. It will also provide opportunities for peacemakers to pursue an inclusive, all-encompassing peace that can be sustained, not least because it concentrates attention on mutually held goals by people of the target society and their leaders. That such an approach will always lead to lasting peace is however, not a forgone conclusion. Such is the complexity of peace processes and the leadership dynamics that surround them. The outcomes are not easily predicted. But this framework at least, provides consistency in the assessment of progress and the delivery of tangible outcomes. Finally, change is an inevitable outcome of a process-based leadership approach. Whether or not the approach produces positive or negative outcomes for peace, a new situation is created. In a new situation, there is always an opportunity for new ideas and new leaders to assert influence in response to the new situation. The potential for change and the opportunities to reinvent peacebuilding during moments of change is perhaps the most dynamic aspect of this approach.

*'Funmi Olonisakin is a Professor of Security, Leadership and Development at King's College London.

\section{BIBLIOGRAPHY}

Ake, Claude (1981), A Political Economy of Africa (New York: Longman)

Boutros-Ghali, Boutros (1992) An Agenda for Peace: Preventive Diplomacy, Peacemaking and Peacekeeping, Doc A/47/277 - S/24111, United Nations, 17 June 1992. Available at: http://www.un.org/Docs/SG/agpeace.html (Accessed 15 April 2015)

Boutros-Ghali, Boutros (1995), Supplement to An Agenda for Peace, Position Paper of the Secretary-General on the Occasion of the Fiftieth Anniversary of the United Nations, Report of the Secretary-General on the Work of the Organization, Doc. A/50/60 - S/1995/1, 3 January 1995. Available at: http://www.un.org/Docs/SG/agsupp.html (Accessed 15 April 2015)

Brautigam, Deborah, Odd-Helge, Fjeldstad, and Moore, Mick (2008), Taxation and State-Building in Developing Countries: Capacity and Consent (Cambridge University Press)

Call, Charles T. and Cook, Susan E. (2003), 'On Democratization and Peacebuilding.' Global Governance, 9(2), pp. 233-246. 
Call, Charles T. and Cousens, Elizabeth M. (2008), 'Ending Wars and Building Peace: International Responses to War-Torn Societies,' International Studies Perspectives, 9(1), pp. 9-21.

Chutel, Lynsey (2017), "The African award that seems to pride itself on not finding a winner strikes out again", Quartz Media LLC, 28 February. Available at: https://qz.com/920981/the-2016-mo-ibrahim-prize-for-african-leadershipchoose-not-name-a-winner/(Accessed 3 June 2017)

Cousens, Elizabeth M. and Kumar, Chetan (eds), Peacebuilding as Politics:

Cultivating Peace in Fragile Societies (Bouler and London: Lynne Rienner, 2001)

Cartwright, John (1983), Political Leadership in Africa (New York: St. Martin's Press)

Galtung, Johan, (1969), 'Violence, Peace and Peace Research', Journal of Peace Research, 6(3), pp. 167-191

Gberie, Lansana (2005), 'Liberia's War and Peace Process', in FB Aboagye and AMS Bah, A Tortuous Road to Peace: The Dynamics of Regional, UN, and International Humanitarian Interventions in Liberia, ISS, Pretoria, pp. 51-70.

Grint, Keith (2010), Leadership: A Very Short Introduction (Oxford: Oxford University Press)

Gutteridge, William (1964), Armed Forces in New States (Mimeo)

Gyimah-Boadi, Emmanuel and van de Walle, Nicolas (1996), 'The Politics of Economic Renewal in Africa', in BennoNdulu et al, Agenda for Africa's Economic Renewal (Newbrunswick: Transaction Publishers).

Hayward, Fred (1984), 'Political Leadership, Power and the State:

Generalizations from the Case of Sierra Leone', African Studies Review, 27(3), pp. 19-39.

Heifetz, Roland (1994), Leadership without easy answers, The Belknap Press of Harvard

Heifetz, Roland A. and Linsk, Marty (2002), Leadership on the Line: Staying Alive through the Dangers of Leading, Harvard Business School Press

Hyden, Goran and Bratton, Michael (eds) (1992), Governance and Politics in Africa (Boulder CO: Lynne Rienner Publishers) 
Hinkin, Timothy R., and Schriesheim, Chester A. (1989). Development and application of new scales to measure the French and Raven (1959) bases of social power. Journal of Applied Psychology, 74(4), 561-567

Homans, George Caspar (1961), Social behavior: Its elementary forms (New York: Harcourt, Brace and World)

Hyden, Goran (1992), 'Governance and the Study of Politics', in Goran Hyden and Michael Bratton, Governance and Politics in Africa (Boulder, Colorado; Lynne Rienner Publishers)

Jackson, Robert and Rosberg, Carl (1985), 'The Marginality of African States', in Gwendolen M Carter and Patrick O'Meara (eds), African Independence: The First Twenty-Five Years (USA: Indiana University Press)

Janowitz, Morris (1964), The Military in the Political Development of New Nations: An Essay in Comparative Analysis, (Chingo: University of Chicago Press)

Johnston, Anton (1998), 'On Developing Institutions in Africa', in Lennart Wohlgemuth, et al, Leadership and Institution Building in Africa (Nordiska Africa Institute, Uppsala)

Kreutz, Joakim (2010), 'How and when armed conflicts end: Introducing the UCDP conflict termination dataset', Journal of Peace Research, 47(2), pp.243-250.

Lacina, Bethany and Gleditsch, Nils P. (2005), Monitoring Trends in Global Combat: A New Dataset of Battle Deaths, European Journal of Population, 21, pp. 145-166.

Lederach, John Paul (1995), Preparing for Peace: Conflict Transformation Across Cultures (NY: Syracuse University Press)

Lederach, John Paul (1997) Building Peace: Sustainable Reconciliation in Divided Societies (Washington, DC: United States Institute of Peace Press)

Lederach, John Paul (1999), Just peace - The Challenge of the Twenty-First Century (Utrecht: European Center for Conflict Prevention)

Lederach, John Paul (1999), The Journey Toward Reconciliation (Pennsylvania: Herald Press)

Lederach, John Paul, People Building Peace. Available at www.gppac.net 
Lemarchand, Rene (1972), 'Political Clientelism and Ethnicity in Tropical Africa: Competing Solidarities in Nation Building', American Political Science Review, 66(1), pp. 68-90

Licklidier, Roy (1995), 'The consequences of negotiated settlements in civil wars, 1945-1993', American Political Science Review 89(3), pp. 681-690

MacGinty, Roger and Richmond, Oliver (2009), Liberal Peace and Post-War Reconstruction, Routledge, for a more expansive discussion.

Mo Ibrahim Index of Governance. Available at http://mo.ibrahim.foundation/iiag/downloads/

MONUSCO, http://www.un.org/en/peacekeeping/missions/monusco/facts.shtml

Murphy, Albert J. (1941), A Study of the Leadership Process, American Sociological Review, 6, pp. 674-687, Reprinted in Jon L. Pierce and John W.

Newstrom (2008) Leaders and the leadership process, pp. 12-14.

North, Douglass (1990), Institutions, institutional change and economic performance (Cambridge: Cambridge University Press)

Northouse, Peter G. (2016), Leadership: Theory and Practice (Sage), pp. 161-193;

Pierce, Jon L. and Newstrom, John. W., (2008), Leaders and the Leadership process: Readings, self-assessments and applications (Boston: Mcgraw Hill)

Pierson, Christopher (2004), The Modern State (London: Routledge)

Picciotto, Robert, Olonisakin, Funmi and Clarke, Michael (2007), Global Development and Human Security (New Brunswick: Transaction Publishers)

Pye, Lucien (1993), Politics, Personality and Nation-Building (New Haven, CT: Yale University Press)

Reychler, Luc (1999), Democratic Peace-Building and Conflict Prevention: The Devil is in the Transition (Leuven University Press: Leuven)

Reychler, Luc and Stellamans, Anton, (2004), 'Researching PeaceBuilding Leadership,' Paper presented at the Conflict Resolution and Peace Building 
Commission (CRPB) at the International Peace Research Association in Sopron, Hungary, July 2004

Richmond, Oliver P. (2008), Peace in International Relations (Routledge: London)

Richmond, Oliver P. (2016), Peace formation and political order in conflict affected societies, Oxford Scholarship Online.

Taylor, Adam (2015), "The sad story of Africa's most prestigious prize", Washington Post, 4 March. Available at: https://www.washingtonpost.com/news/worldviews/wp/2015/03/04/thesad-story-of-africas-most-prestigious-prize/?utm term=.e141d0306a9c (Accessed 3 June 2017)

Tilly, Charles. (1985), 'War Making and State Making as Organized Crime.' In Bringing the State Back in, eds. Evans, Peter B, Dietrich Rueschemeyer, and ThedaSkocpol. Cambridge University Press: New York, Ny. 169-191.

United Nations (2007), Economic Report on Africa: Accelerating Africa's Development Through Diversification

United Nations Department of Economic and Social Affairs (2007) The Challenges of Restoring Governance in Crisis and Post-Conflict Countries, UN- DESA and UNDP, $7^{\text {th }}$ Global Forum on Reinventing Governance Vienna, 26-29 June, pp. 1417

VonDoepp, Peter (2009), 'The Leadership Variable in Africa: Situating Structure and Agency in Governance Trajectories', Paper prepared for the 2009 Annual Meeting of the American Political Science Association, September 4, 2009, pp.3-4

Weber, Max, Gerth, H. Heinrich, and Mills, C Wright, (eds.), trans, 1946, From Max Weber: Essays in Socioplogy, (Oxford University Press: New York), pp. 77-128

Werner, Suzanne (1999), 'The precarious nature of peace: Resolving the issues, enforcing settlement, and renegotiating the term', American Journal of Political Science, 43 (3), pp. 912-934

World Bank (2007), Leadership for Development Results: Country Case Studies (Washington DC: The World Bank Institute)

World Bank (2009), Economic Development and the Quality of Legal Institution. Available at 
Leadership and Developing Societies

Vol 2 No 1, pp. 1-30

http://siteresources.worldbank.org/INTLAWJUSTINST/Resources/LegalInstitut ionsTopicBrief.pdf (Accessed 3 June 2017)

Zartman, I. William and Deng, Francis (eds) (1990), Conflict Resolution in Africa, (Brookings Institution) 